\title{
Solo man in question: Convergent views to split Indonesian Homo erectusin two categories
}

\author{
Valéry Zeitoun \\ UMR 9993- Musée Guimet, 19 avenue d’Iéna, 75116 Paris, France
}

Florent Détroit \& Dominique Grimaud-Hervé

UMR 7194- Département de Préhistoire, Muséum national d’Histoire naturelle, 1 rue René Panhard, 75013 Paris, France

\section{Harry Widianto}

Balai Arkeologi, Jl Gedongkuning 174, Kota Gede, 55171 Yogyakarta, Indonesia

\begin{abstract}
Between the famous Man of Java and the new star of paleoanthropology id est the Man of Flores, embedded in the bank of the river Solo or in the shadow of the volcanoes of Sangiran, Homo erectus remains apart. Driven from evolved Homo erectus to archaic Homo sapiens, for a long time Solo man did not find a real place in taxonomy and in the scientific debate, whereas Neandertal is still famous for its cultural or biological struggle against the ancestors of modern humans. Are there two human evolutionary trends: one in Europe with its first inhabitants over 1.3 Ma that became Neandertals, and another one in Asia, where human fossils are assessed to be older than 1.5 Ma? In 1932, Oppenoorth described Homo (Javanthropus) soloensis from the skull series gathered from the deposits of the Solo River. Since that time, some authors followed the point of view that this series belong to archaic Homo sapiens, but most paleoanthropologists considered them as evolved Homo erectus. To take stock of the taxonomy of Indonesian Homo erectus, three independent approaches and the authors' research done using different techniques and methods were compared. Considering the studies separately undertaken on Homo erectus (Brain structure analyses, 3D morphometry study, cladistic analysis performed from a biometric and morphological database), two categories existed. As far as a chronological gap splits these two categories, this reappraisal of Homo erectus poses the question of the possible occurrence of two different species. This question is still debated among the authors, but the convergent point of view brings new light on the multi-regionalism hypothesis within Homo. This Asian point of view sheds light on the older European evidence of human inhabitants.
\end{abstract}

\section{Introduction}

The phylogenetical pattern of hominids has to be considered as the fundamental background without which it is impossible to bring any significant answer to questions concerning the rate and the mode of evolution of hominids. This is the reason why, when proposing a global scenario for human evolution, it is necessary to use- independently - biological, chronological and environmental data. The phylogenetical pattern has to be strictly built from an anatomical point of view (morphology and metrics). The next step is to describe the evolutionary processes using evolutionary pattern and dating. Finally, when considering environmental data, it is possible to suggest hypotheses around the events that might have triggered the evolutionary processes. European inhabitants are attested to be older and older according to lithic discoveries (Moncel, 2008). In such a global context, what could be the value in the sample of far-eastern Asia where human fossils are present for more than $1.5 \mathrm{Ma}$ ?

\section{The Asian background in paleoanthropology}

In 1932, Oppenoorth described the species Homo (Javanthropus) soloensis from the observations of the human skulls discovered in the deposits of the banks of the Solo River (Oppenoorth, 1932). He stated their phylogenetic place as a geographic variant similar to African Homo rhodesiensis (Oppenoorth, 1937). As early as 1940, Dubois called them Homo sapiens soloensis (Dubois,1940). Although Solo men were initially referred as either Homo soloensis or Homo sapiens soloensis, von Koenigswald considered them as tropical Neandertals (Koenigswald, 1958). In 1962, following the work of Dobzhansky (1944) and Mayr (1957), at the anthropological symposium of Wartenstein (Liptak, 1969) it was concluded that only two species have to be recognized within the genus Homo: Homo erectus and H. sapiens (Campbell, 1963). At this occasion Solo 
men as well as Neandertals were included in the species H. sapiens. Tobias is the only researcher who regularly used the full trinomen H. sapiens soloensis (Tobias, 1985), but several authors (Jelinek, 1981; Stringer, 1987; Bonde, 1989; Braüer and Mbua, 1992; Hawks et al., 2000) considered them as "archaic" H. sapiens. Jacob, the curator of the fossils (after von Koenigswald), disagreed with this grouping (Jacob, 1978) and was, indeed, followed by the majority of the authors who preferred to call them "advanced" or "evolved" $H$. erectus. This trend was certainly influenced by the work of Weidenreich $(1943,1951)$ who considered them as a geographical morph and relatives of Peking man, and also by the study of Santa Luca (1980) considering their rank as H. erectus. However, the work of Macintosh and Larnach (1972) showed that the thickness of the cranial vaultwas not a typical trait of $H$. erectus. This conclusionwas confirmed by Brown (1994) and more recently through CT-scan analyses of the fossil cranial vaults (Balzeau, 2005).

The "Ngandong series", which was initially composed of the fossils from Ngandong only, is now extended to the specimens recovered from Ngawi and Sambungmacan (Grimaud-Hervé et al.,1998; Widianto and Grimaud-Hervé, 2001; Widianto and Zeitoun, 2003; Baba et al., 2003). Initially dated about 250,000 years, new data suggests a more recent age around 25,000-50,000 years (Swisher et al., 1996) or slightly older between 60,000 and 70,000 years (Falguères et al., 2001; Yokoyama et al., 2008). Accordingly, Solo men are nowadays frequently considered as demonstrably persistent representatives of $H$. erectus, well into the Upper Pleistocene (Clark Howell, 1999). They are commonly considered as the descendants of the "classic" $H$. erectus (Trinil-Sangiran series) but nothing else is proposed for them in terms of evolutionary process.

\section{Material and method of the different analyses.}

It has long been recognized that Asia shows particular paleoanthropological perspectives for the PlioPleistocene. Indeed, apart from the issue of Meganthropus and Gigantopithecus, the question of the coexistence of at least two human categories is still open. Almost all the analytical works conducted during the last three decades on the early Indonesian specimens propose a classification based on the recognition of at least two different categories (Sartono and Grimaud, 1983; Bra"uer and Mbua, 1992; Widianto, 1993; Grimaud-Hervé, 1997 and many others): the "classic" H. erectus or H. erectus on one hand, and the "evolved" H. erectus or "archaic" H. sapiens on the other hand. This paper considers three independent points of view concerning the description, analysis and interpretation of the Solo series.

\section{Brain structures analyses}

The brain is an exceptional subject of research, because even if its evolution is in close relationship with the skull, derived encephalic morphological features appear in mosaic patterns, sometimes before cranial ones. Some differences, but also some similarities emerge from morphological brain study in Javanese fossil hominids. The endocast samples of early Javanese hominids include Sangiran 2, 10,12, 17 and 38, from Bapang (Kabuh) formation dated between 0.7 and 1 million years (Salecki, 1997; Sémah et al., 2000; Falguères, 2001) as well as Trinil 1. Younger endocast samples include the hominid fossil remains from Ngandong 1, 2, 3, 5, 6, 7, 9,10, 11 and 12, and Sambungmacan 1 and 3. These endocranial fossil remains were compared to anatomically modern H. sapiens (N. 103) from Europe, continental and insular Asia, Africa, America and Oceania. The preservation of the Sangiran, Trinil and Solo hominids is quite good. Physical endocasts obtained directly from the internal cavity of incomplete skulls reveal the exact internal surface of the cranial bone. Because Ngandong 7, 12, Sambungmacan 1 and 3 are more complete specimens (the basicranium, or major part of it, is preserved), physical endocasts were difficult to realize, and endocasts were obtained from CT-scan data (Balzeau et al., 2002; Balzeau, 2005). The Chinese sample includes endocasts of the H. erectus from Zhoukoudian Lower Cave Locus D (Ckn.D 1.PA.17. "Skull II"), Locus E (Ckn.E 1.PA.16 “"Skull III”, and Locus L (Ckn.L 1.PA.98 “"Skull X, Ckn.L 2.PA.99 “"Skull XI” and Ckn.L 3.PA.100 "Skull XII"). They are chronologically situated between 0.4 and $0.78 \mathrm{Ma}$ (Shen et al., 2009). In order to eventually characterize autapomorphies of the H. erectus species, the results have been compared with more or less contemporaneous fossil hominids recovered from Africa and Europe. The sampling consists in African Homo ergaster from East Turkana (KNMER 3733 and 3883) and West Turkana (KNM WT 15000) in Kenya and H. sapiens (Salé, Jebel Ihroud 1 and 2) from Morocco. European fossil specimens pertaining to the Neandertalian lineage are Arago 21 and 47 (France), Swanscombe (Great Britain), Reilingen (Germany), Biache-Saint-Vaast 1 (France), Neandertal (Germany), Spy 1 and 10 (Belgium), Le Moustier 1, La Chapelle aux Saints, La Ferrassie 1 and La Quina H5 (France). The morphological study concentrates on variations of the vascular imprints (cranial sinuses and middle meningeal pattern) and encephalic impressions of each cerebral lobe. 


\section{Geometric morphometrics: 3D Procrustes analysis}

Morphometric analyses are traditionally used in paloanthropology to uncover resemblances and phenetic affinities among fossil hominids. Such approaches have also been applied to the Ngandong specimens to evaluate their taxonomical affinities with H. erectus and/or H. sapiens (see Santa Luca, 1980). Because those fossil skulls exhibit rather large general dimensions related to increased cranial capacities compared to typical H. erectus (Grimaud-Hervé, 1997; Holloway, 1980), traditional morphometric analyses based on linear measurements resulted most of the times in unresolved and / or contradictory morphometrical affinities. Clustering of the Ngandong hominids with anatomically modern $H$. sapiens is sometimes the result obtained from such analysis. This morphometrical proximity is especially pronounced when the "robust" Australian fossil H. sapiens (Cohuna, Kow Swamp and WLH50) are involved in the analyses (Stringer, 1998; Hawks et al., 2000; and see Durband, 2009 for a recent review), despite the fact that some of those specimens are certainly artificially deformed (Brown, 1981, 1989). In order to take into account more precisely the subtle differences which exist in terms of shape and size in such comparisons, a 3D landmarks based geometric morphometrics analysis was undertaken. The Procrustes method allows rigorous statistical analyses of size and shape differences, in association with powerful visualization possibilities throughout the analytical procedures (see for instance Slice, 2005). Procrustes analyses are particularly well suited for taxonomically oriented approaches of the hominid fossil record (Harvati, 2003; Harvati et al., 2004; Terhune et al., 2007; Baab, 2008; Bouée and Détroit, 2008). Previous Procrustes analyses focusing on Indonesian H. erectus and Australian H. sapiens (Détroit, 2002; Sémah and Détroit, 2006) pointed out several morphometric specificities for the Ngandong-Ngawi Sambungmacan series (hereafter referred to as the "Ngandong series"). To understand if a distinct and consistent morphometrical pattern can be seen from size and shape analyses of the Ngandong skullcaps series by comparison with archaic $H$. sapiens and $H$. erectus, analysis deliberately focused on Asian hominins (Table 1). The H. erectus (s.l.) and H. sapiens (s.l.) groups are mainly composed of East Asian, Southeast Asian and Australian fossils. Some African fossils are also used as "reference" individuals for comparisons. The use of the Jebel Irhoud 1 and 2 specimens in our sample makes sense as they are now considered to be two of the few known early anatomically modern $H$. sapiens (Smith et al., 2007). Kabwe 1, whose taxonomic attribution is still debated (see Rightmire, 1996; Stringer, 2002) is included in the analysis as a representative of the hypothetical ancestors of anatomically modern $\mathrm{H}$. sapiens. The analysis involves 27 landmarks localized on the whole skullcap (Table 2), with 7 sagittal landmarks (located on the sagittal midplane) and 2-10 parasagittal landmarks (on the right and left side respectively). The 27 landmarks are well balanced among the three main different types of landmarks defined by Bookstein (1991). Despite their "deficient" properties in terms of biological homology (type III of Bookstein, 1991), Glabella, Opisthocranion and right and left Euryon are included in this set for their geometricbearing, allowing description of the relative positions of maximal length and breadth of the skullcaps. The Cartesian coordinates of all landmarks were digitized with a Microscribe 3DX on original specimens or casts (Table 1). For incomplete specimens, missing landmarks were not estimated during digitization. Parasagittal landmarks which were missing on one of the two sides have been replaced by a mirror of their controlateral equivalent landmark through a symmetrization procedure. This symmetrization procedure was also used in few cases to replace landmarks localized on obviously deformed anatomical portions of interest on one side of the fossil by their controlateral equivalent landmarks from the other side. All Procrustes superimpositions and associated statistics were performed with R (R Development Core Team, 2009), with the package "shapes" (Dryden, 2009) and several functions written by Claude (2008).

Table 1

List of fossil hominids included in the Procrustes analysis.

\begin{tabular}{|c|c|}
\hline $\begin{array}{l}\text { Homo erectus s.l. } \\
\text { "Ngandong series" }\end{array}$ & $\begin{array}{l}\text { KNM-ER } 3733^{\mathrm{a}} \text {; Bukuran; Sangiran } 17^{\mathrm{a}} \text {; Ckn.E 1.PA.16. }{ }^{\mathrm{a}} \text {; L 1.PA.98. }{ }^{\mathrm{a}} ; \text { L 2.PA.99. }{ }^{\mathrm{a}} ; \mathrm{L} \text { 3.PA.100. }{ }^{\mathrm{a}} \text { (referred to as Sin. III, X, XI, XII); Hexian } \\
\text { Ngandong } 1,6,7,10,11,12 \text {; Ngawi : Sambungmacan } 3^{\mathrm{a}}\end{array}$ \\
\hline Homo sapiens s.l. & $\begin{array}{l}\text { Kabwe } 1^{\mathrm{a}} \text {; Jebel Irhoud } 1,{ }^{\mathrm{a}} 2^{\mathrm{a}} ; \text { Dali }^{\mathrm{a}} ; \text { Jinniushan } \\
\text { Minatogawa } 1^{\mathrm{a}} 4^{\mathrm{a}} \text { : Keilor }{ }^{\mathrm{a}} ; \text { Cohuna }{ }^{\mathrm{a}} ; \text { Kow Swamp } 5^{\mathrm{a}} ; \text { Zhoukoudian UC } 101{ }^{\mathrm{a}} 103^{\mathrm{a}} ; \text { Liujiang }^{\mathrm{a}} ; \text { Ziyang }^{\mathrm{a}} \text {; }\end{array}$ \\
\hline
\end{tabular}

${ }^{a}$ Casts examined and digitized, other digitization made on original specimens. 
Table 2

\begin{tabular}{|c|c|}
\hline Landmarks & Description \\
\hline \multicolumn{2}{|l|}{ Midsagittal landmarks } \\
\hline 1. Nasion & Meeting point between the frontal and both nasal bones \\
\hline 2. Glabella & Most anterior point of the glabellar region of the frontal bone \\
\hline 3. Supraglabellare & Maxima of curvature of the supra-glabellar depression \\
\hline 4. Bregma & Intersection point of the coronal and sagittal sutures \\
\hline 5. Lambda & Intersection point of the sagittal and lambdoid sutures \\
\hline 6. Opisthocranion & Most posterior point of the occipital bone, in the midsagittal plane (constructed as the most distant point from the glabella) \\
\hline 7. Inion & Midsagittal meeting point of the left and right parts of the superior nuchal lines \\
\hline \multicolumn{2}{|l|}{ Parasagittal landmarks } \\
\hline 8./18. Frontomalare orbitale & Most anterior point of the frontozygomatic suture (intersection with the inner orbital rim) \\
\hline 9./19. Frontomalare temporale & Most posterior point of the frontozygomatic suture (intersection with the temporal line) \\
\hline 10./20. Frontotemporale & $\begin{array}{l}\text { Point where the temporal line reaches its most anteromedial position on the frontal (constructed as the point of maximal } \\
\text { postorbital constriction of the frontal, on the temporal line) }\end{array}$ \\
\hline 11./21. Stephanion & Intersection point of the upper temporal line with the coronal suture (suprastephanion) \\
\hline 12./22. Auriculare (modified) & $\begin{array}{l}\text { Point where the suprameatal crest reaches its most anteromedial position (maxima of concavity of the suprameatal crest, } \\
\text { usually above the external acoustic meatus) }\end{array}$ \\
\hline 13./23. Porion & Uppermost point on the margin of the external acoustic meatus \\
\hline 14./24. Mastoidal & Most inferior point on the mastoid process (apex of the mastoid process) \\
\hline 15./25. Asterion & Intersection of the lambdoidal, parietomastoid and occipitomastoid sutures \\
\hline 16./26. Euryon & $\begin{array}{l}\text { Point where the crania reaches its greatest breadth (constructed as the point of greatest cranial breadth, on the parietal or } \\
\text { the temporal bone) }\end{array}$ \\
\hline 17./27. Coronale & Point on the coronal suture where the frontal bone reaches its greatest breadth \\
\hline
\end{tabular}

\section{Cladistic analysis}

Hlusko (2004) asserted that "cladistics is a powerful tool for reconstructing phylogenetic relationships, but it is a tool whose power is proportional to the number of independent character available for analysis." These objections arise from a quantitative vision commonly adopted by neontologists who forget that in cladistics (see Hennig, 1966), a unique autapomorphy suffices to distinguish a taxon. Hlusko (2004) and many others also object to cladistics, claiming that the evolution is not sufficiently parsimonious. This is certainly the case but the scientific method which describes the evolutionary process has to be so in order to avoid the multiplication of hypotheses presented in ad hoc fashion which support a result. Taking into account the greatest possible number of fossils but also in order to avoid the problems resulting from the large amount of missing data (most of the fossils being incomplete), only the best preserved skulls are kept for the following cladistic analysis. The selection includes calvaria of the African "early" Homo, "H. erectus"or "H. ergaster", Asian " $H$. erectus" include the type specimen and Chinese specimens used for the assessment of their regional range. "Archaic H. sapiens" from Africa and Asia, Neandertals from Europe and Middle East are taken into account because there are potentially contemporaneous. Modern humans are used for comparison. Thus it is possible to have one of the widest spectrums for the phylogenetic analysis with the smallest bias of sampling. If the study is undertaken at an individual level, it is also necessary to split each anatomical feature into its elementary parts. Accordingly, the variation of the morphological features of the skull is used at elementary levels for each bone (frontal, parietal, temporal, and occipital), and metrical data are taken into account on these bones either from different points of view or in different planes. From this anatomical work, 123 morphological features can be compared. Some of them provide a description of a relative position, size and pattern of anatomical elements by comparison with others. A complete definition of these features and a discussion of their variation have already been published (Zeitoun, 2000a). It was also decided to make use of an index as they provide semi-quantitative information that is more precise than morphological descriptions relative to size. This kind of data is therefore preferred when homologous points are present. When this is not the case, morphological descriptions (more or less rounded, linear/curved, etc.) are used. Two different kinds of index are used for 38 distinct points. Among all possible indexes calculated from the 38 anatomical landmarks, the selected indexes are those that allow us to split samples of individuals from part or all of the global sample. This global sample is composed of modern humans and apes, australopithecines and human fossils. In this way, for each index, each subgroup of specimens is characterized by an ordinal score, relative to that of the modern human sample. With this method, 345 metrical indexes are held, allowing us to distinguish different categories, whereas 1919 indexes are similar for all the sub-groups: apes, modern humans, human fossils and australopithecines). They are symplesiomorphy for the Primates taken into account and are of no use in the present study. The final cladistic analysis was carried out with 123 morphological and 345 metrical features and was conducted on 30 OTUs: 27 specimens and 3 modern samples (Modern humans, Pan troglodytes and Gorilla gorilla). The full cladistic definition of features and the diagnoses of the species are available in Zeitoun (2009). 


\section{Results of the different analyses Brain structures analyses \\ Vascular impressions}

Concerning cranial sinuses, the most noticeable feature is the spheno-parietal sinus localized in the posterior part of the frontal lobes in front of the central sulcus. Usually detected in its most reduced form on endocasts from Trinil and Sangiran, its presence has not been noted on the specimens from Sambungmacan (Balzeau et al., 2002) and Ngandong, nor on the H. ergaster and archaic H. sapiens from Africa (Grimaud-Hervé, 2004). On the contrary, it is always present on Neandertals with accentuated relief (unfortunately, this cortical region is never preserved on the earlier representatives of this lineage), and is considered as an autopomorphy of this species. The pattern of the middle meningeal vascular system shows an obelic (middle) branch with a double origin with equivalent contributions of the anterior and posterior branches in Trinil and Sangiran hominids, like on $H$. ergaster and the majority of Chinese H. erectus. On more recent hominids from Africa, Europe and Asia and also on modern H. sapiens endocasts, the most frequent pattern exhibits an anterior system with a ramified obelic branch. On the African $H$. sapiens and reference sample of $H$. sapiens, the number of ramifications increases considerably, with more anastomoses which constitute a dense squaring pattern on the encephalic surface. The opposite process is observed, with a drastic reduction of the number of ramifications, on more recent adult hominids from Indonesia (Ngandong) and Europe (Neandertals). Perhaps this may be interpreted as parallel evolutionary trends for these two geographically populations that have evolved in isolated places (Java and Europe). Thus, concerning meningeal vascularization, differences appear between Asian $H$. erectus compared to fossil hominids from Africa and Europe in one hand, and between ancient and more recent fossil specimens in Europe and Indonesia. This reduction of middle meningeal vascularization pattern could be interpreted as an evolutionary trend in those species: Preneandertals to Neandertals in Europe, and from classical H. erectus to evolved $H$. erectus in insular Asia.

\section{Encephalic imprints}

The shape of the encephalic rostrum (extension of the anterior regions of the first frontal convolutions) is long and narrow for African H. ergaster, as well as for Sangiran and Zhoukoudian Lower Cave H. erectus; these cerebral regions are shorter and wider on Ngandong and Sambungmacan endocasts, as confirmed by Broadfield et al. (2001) on Sambungmacan 3. In relation with a large interorbital space, the encephalic rostrum is developed on the early fossil hominids, and becomes reduced on later hominids until it is no longer apparent on $\mathrm{H}$. sapiens. The evolution of this feature is functionally correlated with a reduction of the olfactory capacities. Moreover, the outline is regularly concave for African specimens, but is made of two sections which meet and form a marked angle for Asian specimens (Fig. 1). This morphological feature is particular to Asian H. erectus but does not distinguish the Sangiran-Trinil group from the NgandongSambungmacan group. Two important characteristics of the components of the third frontal convolution have been reported for Javanese fossil hominids. The first one corresponds to the development of Broca's area, which is laterally enhanced in the Ngandong and Sambungmacan specimens compared to the Sangiran-Trinil group. The second feature is the position of Broca's area, which is clearly situated in front of the temporal pole for Sangiran-Trinil endocasts, while it is located above the temporal pole for Ngandong-Sambungmacan. On Sangiran-Trinil endocasts, the Sylvian valley is wide and shallow, and followed by a lateral sulcus which is oblique and curved upwards at the end. It becomes slightly narrower on Ngandong-Sambungmacan series. This succession of modifications is also observed on H. sapiens or Homo neanderthalensis species, with the same distinction between ancient and more recent specimens, so it cannot be interpreted as autapomorphic, but corresponds to evolutionary stages. The distinction between Sangiran-Trinil fossil hominids and Ngandong-Sambungmacan appears clearly. The endocranial outline in anterior view is distinct for African $H$. ergaster (Fig. 1) compared with Asian H. erectus and European fossil hominids. It is narrow, high and regularly convex without interruption in the transversal cerebral curvature for African $H$. ergaster, while it is wider, lower and with a less pronounced convexity which is broken in the medial region of the frontal lobes for Asian $H$. erectus. On parietal ones, a depression corresponds to a middle frontal sulcus and interparietal sulcus. This sigmoid curve is less pronounced on $H$. neanderthalensis and $H$. sapiens. Pre- and post-central convolutions breadths are nearly equivalent for African hominids and ancient Asian H. erectus. Ngandong and Sambungmacan exhibit more developed precentral gyrus, which corresponds to an increase of motor area. The same development is also observed on European specimens. Post-central convolution is equivalent or more developed on $H$. sapiens. A trend with an increased development and individualization of the parietal cerebral components is observed between the two 
Javanese hominids groups, as well as in Europe and Africa. This feature is in relation with tactile sensibility. The endocranial lateral view exhibits a different outline. For African hominids, the occipital lobes are situated in the continuity of the parasagittal curvature, forming an uninterrupted convexity. They are not bulging and slightly convex. On the contrary, the occipital lobes are clearly projecting backwards in the prolongation of the parietal and temporal lobes on Sangiran-Trinil endocasts. Little difference appears on Ngandong-Sambungmacan endocasts, with occipital lobes situated slightly under the parietal and temporal lobes. The pattern is completely different on $H$. neanderthalensis and $H$. sapiens, with a more anterior and inferior position of the occipital and cerebellar lobes, as a result of occipital rounding. This trend of closing of cerebro-cerebellar excavation between Sangiran-Trinil and Ngandong-Sambungmacan is noticed as between frontal and temporal lobes which is functionally associated to prevision and deliberation. Therefore, some results of the analysis of morphological brain features distinguish Asian H. erectus from African and European hominids. Several features also split the Indonesian fossil record into the SangiranTrinil series on one hand and the Ngandong-Sambungmacan series on the other hand.

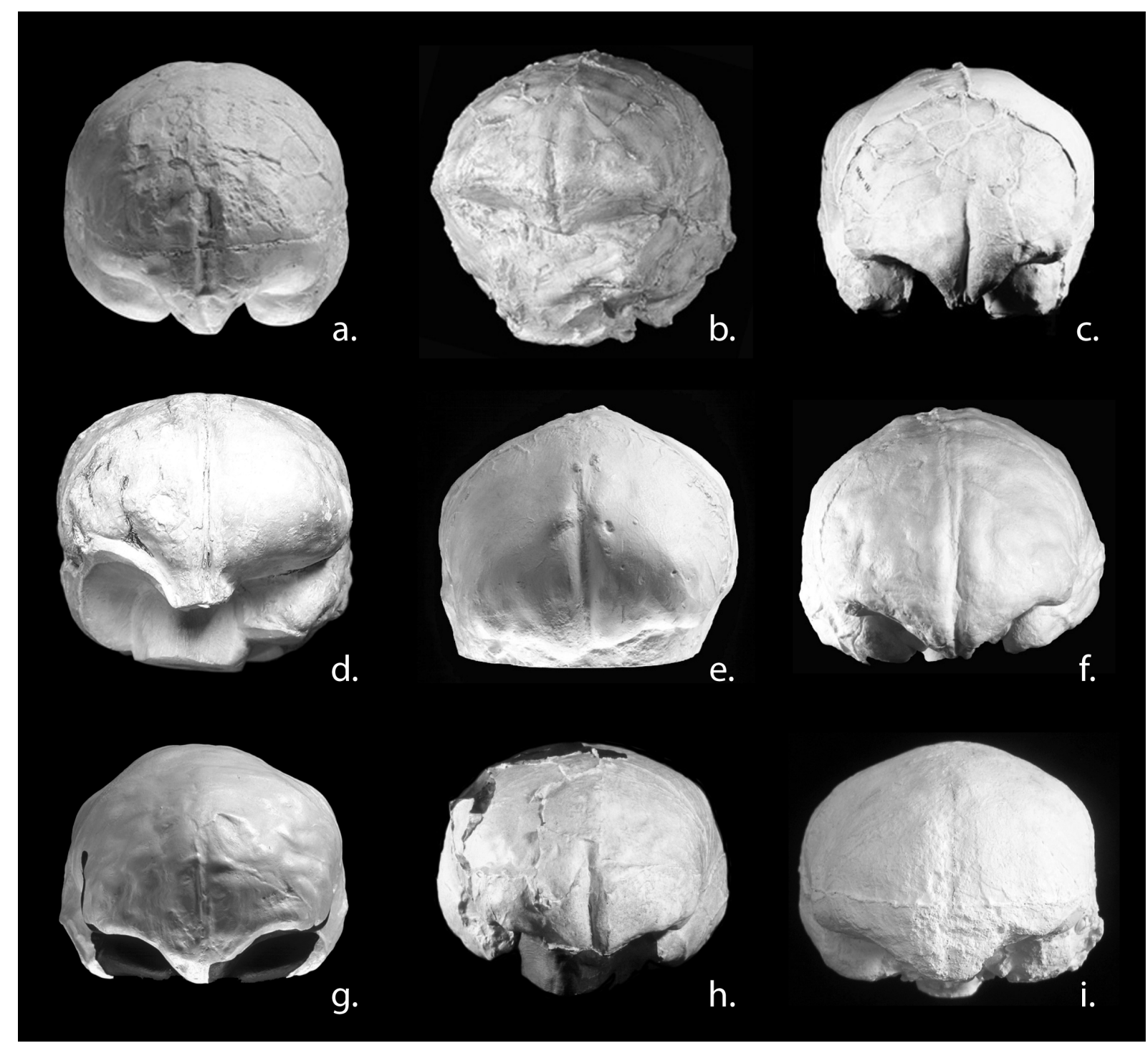

Fig. 1. Endocranial casts (anterior views) of: (a) KNM-ER 1813; (b) KNM-WT 15,000; (c) Arago 21 and 47; (d) La Chapelle aux Saints; (e) Cro Magnon 3; (f) Sinanthropus III; (g) Sinanthropus XII; (h) Sangiran 17; (i) Ngandong 7.

\section{Results of the geometric morphometrics: $3 D$ Procrustes analysis}

The scatterplots of individuals on PC1-PC2 (57.4\% of the total variation) and PC1-PC3 (55.3\%) of the principal component analysis of fitted Procrustes coordinates gives a clear patterning of the specimens involved in the analysis (Fig. 2). According to shape differences explained along PC1 (which accounts for $48.8 \%$ of the total variation) a clear distinction is made between $H$. erectus s.l. (including the Ngandong series) 
which fall on the positive side of the axis, and $H$. sapiens which fall onthe negative side of PC1. Corresponding shape differences are respectively: low, narrowand elongated skullcaps for positive values on PC1, and relatively higher, wider and shorter skullcaps for negative values on PC1. Following this clear trend along PC1, specimens such as Jebel Irhoud 1 (Morocco), Dali and Jinniushan (China) have scores around 0 for PC1 and show "intermediate" shapes (i.e. in between the group which includes H. erectus and earlier African specimens and the group of H. sapiens). As far as the Ngandong-Ngawi-Sambungmacan fossils are concerned, they show absolutely no morphometric affinities with anatomically modern $H$. sapiens. The Ngandong series falls toward the most positive values for PC1, along with earlier Indonesian H. erectus and earlier African specimens. It is observed however that fossils such as Sambungmacan 3 and "Sinanthropus" III return the lowest scores for PC1 among the H. erectus s.l. group. A possible explanation could be found in their non-adult individual age estimates (Weidenreich, 1943; Delson et al., 2001). Thus, they may not exhibit the fully developed shapes of their skullcaps. While grouped according to PC1, the specimens of the Ngandong series are clearly separated from the other H. erectus (s.l.) on PC2 and PC3, which account respectively for 8.6 and $6.6 \%$ of the total variation. The two groups are marginally overlapping on PC2, but are completely distinguished on PC3. Corresponding shape differences are mainly visible in upper view where the specimens from the Ngandong series exhibit a general widening of the middle and anterior parts of the skullcap whereas $H$. erectus present a very strong constriction behind the supraorbital torus.
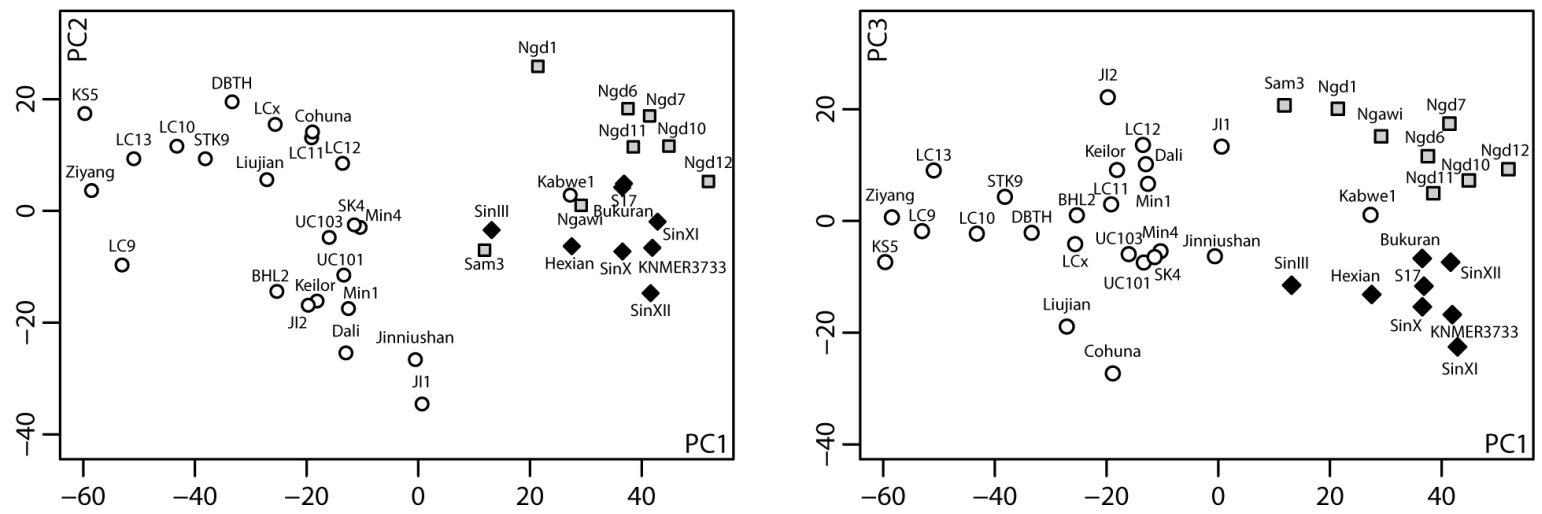

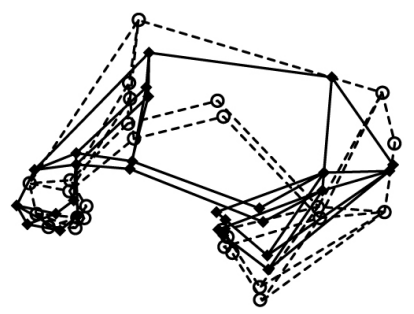

PC1

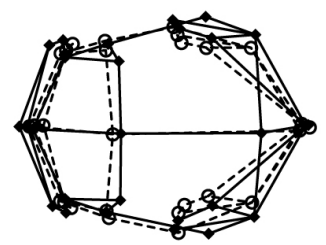

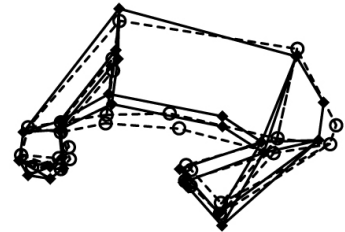

PC2

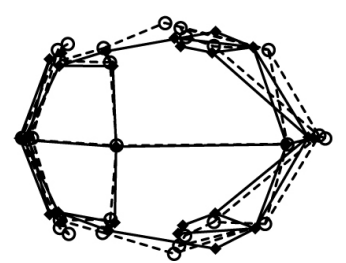

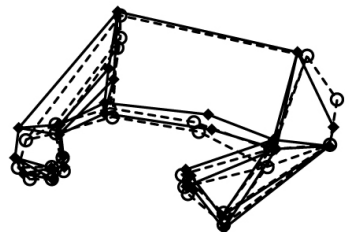

PC3

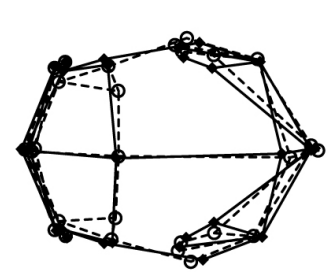

Fig. 2 .

Principal Components Analysis of Procrustes residuals: scatterplots on shape components (PC1-PC2 and PC1-PC3); and associated shape variations along PCs (black dots and continuous lines correspond to positive values along PCs, open circles and dotted lines correspond to negative values along PCs). Black diamonds: "Homo erectus", Sin, Sinanthropus (Zhoukoudian); S, Sangiran. Grey squares: "Ngandong series", Ngd, Ngandong; Sam, Sambungmacan. Open circles: "Homo sapiens", KS, Kow Swamp; LC, Lang Cuom; DBTH, Da But Tan Hoa; BHL, Braholo; SK, Song Keplek; ST, Song Terus; Min, Minatogawa; UC, Upper Cave (Zhoukoudian); JI, Jebel Irhoud.

A MANOVA (Hotelling test) of the individual scores for the first 5 principal components (almost $76 \%$ of the total variation) gave significant differences at the $1 \%$ level for three groups (Df $=2$ and 37; HotellingLawley $=10.822$; approx. F=34.630; num. $\mathrm{Df}=10$; den. $\mathrm{Df}=64 ; \mathrm{p}<2.2^{\mathrm{e}}-16$ ). Shape differences between the 
three groups are easily seen on the direct comparison of the three consensus (mean shapes calculated from the Procrustes aligned 40 specimens: Fig. 3). Almost no differences are seen in lateral view between the "H. erectus" and "Ngandong series" consensus, except for a more posterior However, the upper and anterior views showa clear widening of the frontal squama in the Ngandong series, reaching a "H. sapiens" shape, but in association with a supra-orbital complex closer to H. erectus. The specimens from the Ngandong series exhibit a general " $H$. erectus" shape pattern of their skullcap with a well developed supra-orbital complex, a sharp angle between the nuchal plane and the occipital squama, and a long and low braincase, but with a remarkably enlarged width of its anterior part, with the two sides being almost parallel in upper view. Shape differences between the three groups were further examined with the Hotelling test carried out on Procrustes residuals. The "test-mean-shapes" function of the package "shapes" (Dryden, 2009; and see Dryden and Mardia, 1998), which includes a regularization of the procedure for low sample sizes, was used. The differences for mean shapes of each group were tested by pairs, with 1,000 permutations. The differences between mean shapes are statistically significant at the $5 \%$ level for all the combinations : $H$. erectus-"Ngandong series" (p . 0.039 based on resampling), H. sapiens "Ngandong series" (p. 0.0009 based on resampling) and H. sapiens-H. erectus (p . 0.0009 based on resampling). Differences in the shapes of the skullcaps are also possibly accompanied by size changes. When centroid size is considered, the Ngandong series tends to show larger size than the two other groups (Fig. 4), but only the difference between $H$. sapiens and the "Ngandong series" is statistically significant at the $5 \%$ level with a permutation t test for equality of means (H. sapiens: $\mathrm{n}=24$, mean $=417.03$; "Ngandong series": $\mathrm{n}=8$, mean $=437.73$; $\mathrm{t}=-2.6377$; $\mathrm{p}<0.05$ based on 10,000 permutations).
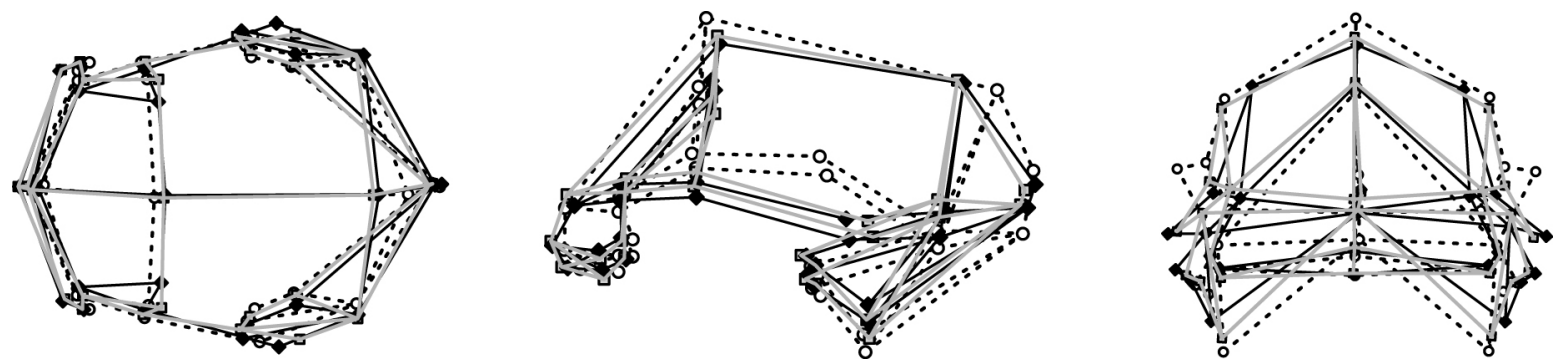

Fig. 3.

Upper, lateral and anterior views of the mean shapes (consensus) calculated for the three groups of hominins included in the Procrustes analysis: Black diamonds and lines: "Homo erectus" (consensus of 8 fossil specimens). Grey squares and lines: "Ngandong series" (consensus of 8 fossil specimens). Open circles and dotted lines: "Homo sapiens" (consensus of 24 fossil specimens).

\section{Results of the Cladistic analysis}

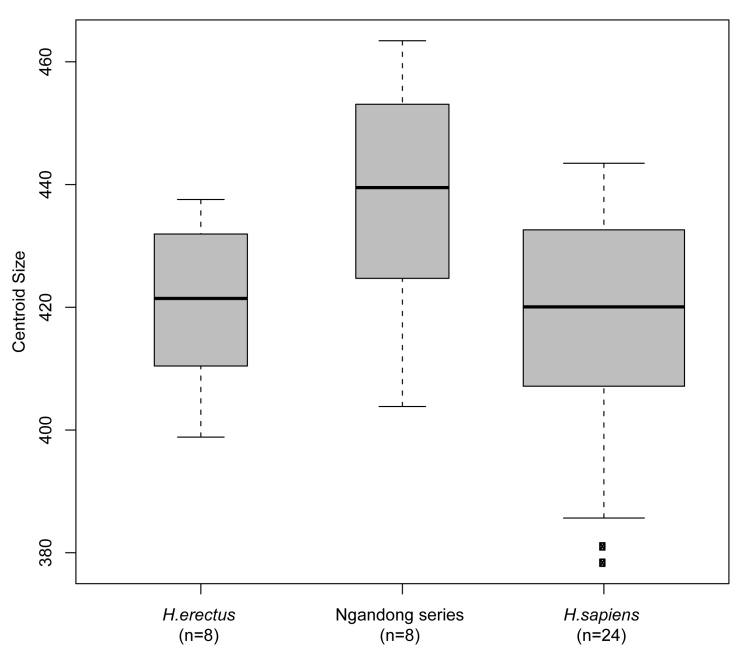

The result of the cladistic analysis is a single tree (Fig. 5) where using the oldest legal names of the specimens present in the clades it is possible to name each clade. Obviously there is an arbitrary decision in this proposal and an unanswered question on the real level of the different clades remains. Are they species, subspecies, or other categories? On the tree shown in Fig. 5, one simple interpretation is to recognize a grade including Homo rudolfensis, $\mathrm{H}$. ergaster and two other species, then $H$. erectus (the cladistic definitions of these species have already been published in Zeitoun, 2009).

Fig. 4.

Centroid sizes comparison for the three groups of hominins included in the Procrustes analysis (box-plot: mean values, standard deviations, extreme values, and outliers; boxes areas are proportional to the number of specimens).

After that node, the question is to read the following branches as a big bough for the unique species $H$. sapiens or for several species, which is globally speaking equivalent to read an "intra $H$. erectus" diversity (Tattersall and Schwartz, 2009) or to conclude to the existence of several species (Schwartz and Tattersall, 2000). The first hypothesis is to interpret the branch in the spirit of the conclusions of the Wartenstein 
conference (Liptak, 1969) with many subspecies of H. sapiens : H. sapiens rhodesiensis in Africa and H. sapiens soloensis in Asia (with the remaining question for a joint name for possibly both- H. sapiens heidelbergensis), and H. sapiens pekinensis, several "archaic" H. sapiens subspecies such as H. sapiens daliensis, H. sapiens neanderthalensis and $H$. sapiens sapiens. In this instance both theoretical models - multiregional and unicentrist- are reconciled because the multiregionalism happens within a single species: H. sapiens (see Zeitoun, 2004). The second hypothesis is to the different clades as different species: H. rhodesiensis, H. soloensis, Homo pekinensis, Homo beidelbergensis, $H$. neanderthalensis and $H$. sapiens. Other interpretations can also be brought considering an intermediary step between these two phylogenetic hypotheses. For instance, the clade of $H$. sapiens could be recognized at the bottom of the clade including the specimen of Bodo as proposed by Rightmire (1986). At least, Solo series and Sangiran-Trinil are split in two different categories as it is the case in the two former kind of approach (see also Schwartz and Tattersall, 2000).

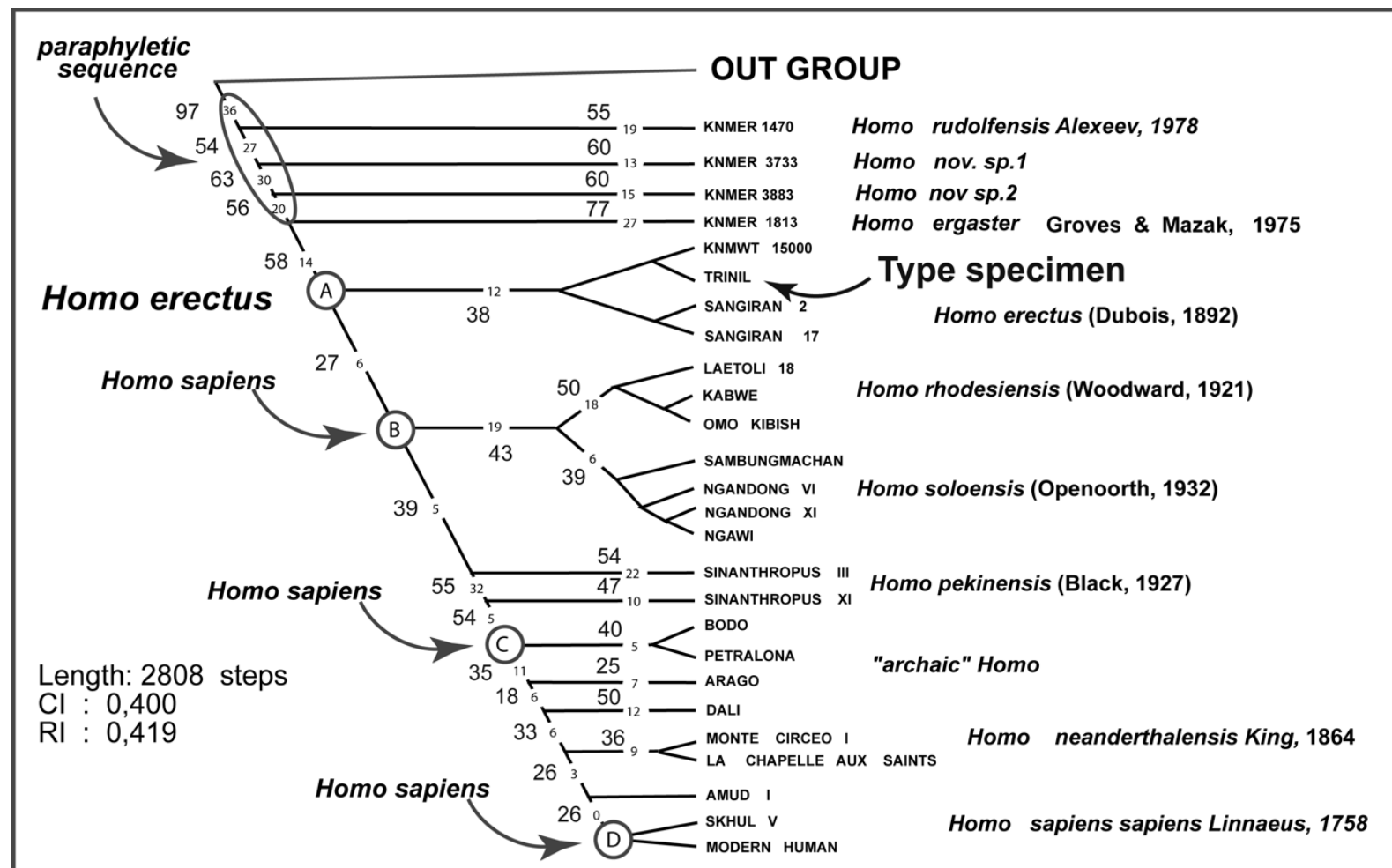

Single Tree with the number of synapomorphies and (in small character), the number of synapomorphies which $\mathrm{Cl}>0.500$

Fig. 5.

Single phylogenic hypothesis. The matrix includes 30 OTUs. The Out-group is made of Sterkfontein 5, KNMER 406, a series of 11 Pan troglodytes and 11 Gorilla gorilla. Modern human is a series of 33 Modern humans and Arago is is both Arago XXI and XLVII. Hypothesis B suggests a series with Homo sapiens rhodesiensis, Homo sapiens soloensis, Homo sapiens pekinensis, archaic Homo sapiens including Homo sapiens heidelbergensis, Homo sapiens neanderthalensis and Homo sapiens sapiens. Hypothesis C suggests a series with Homo rhodesiensis, Homo soloensis, Homo pekinensis, Archaic Homo sapiens including Homo sapiens heidelbergensis, Homo sapiens neanderthalensis and Homo sapiens sapiens. Hypothesis D suggests a series with Homo rhodesiensis, Homo soloensis, Homo pekinensis, Homo heidelbergensis?, Homo neanderthalensis and Homo sapiens.

\section{Convergence of the three analyses}

The different scholars from which belonged the three analyses undertaken in this paper usually provide opposing points of view and lead to conflict between paleoanthropologists. The combined approach leads to recognize a specific diversity, as emphasized by Schwartz and Tattersall (2000) when following the traditional taxonomic procedures to define the species and their hypodigms. It is not possible here to use such a procedure, as phenetics and cladistics used very different way to express what is a species. From Procrustes analysis of the skullcaps, there is a very clear shape difference between $\mathrm{H}$. ergaster- $\mathrm{H}$. erectus and H. sapiens. However, among the former group, a significant additional shape differencewas found, clearly separating the Ngandong series fossils from earlier African, Chinese and Indonesian hominins. The Ngandong fossils show a very particular shape of their skullcaps. It can be described as an overall H. erectus pattern, but with considerably enlarged proportions of the anterior part of the skullcap (frontal squama and greater wings of the sphenoid bone). This shape pattern is consistently found among the Ngandong series as well as in Sambungmacan and Ngawi, but is never observed among Jebel Irhoud, nor in the Chinese fossils from Dali and Jinniushan. Some endocranial morphological characters differ among several human 
categories, such as : (1) cranial sinuses, which distinguish $\mathrm{H}$. neanderthalensis from other fossil hominins with systematic presence of a spheno-parietal sinus, but do not show differences between the series from Sangiran-Trinil and Ngandong-Sambungmacan, (2) the clear decreasing of the middle meningeal squaring pattern on adult recent fossil hominins from Ngandong in South-East Asia and Neandertals in Europe, which show the same evolutionary trend in these two geographically isolated areas, (3) the particular outline of African Homo habilis and H. ergaster compared to Asian and European samples, (4) the development of Broca's area and its position in connection with the temporal pole is different between both Javanese samples; this evolutionary trend is also observed in Europe between ancient fossil hominins compared to more recent ones, (5) the transversal cerebral outline which distinguishes African $\mathrm{H}$. ergaster from other studied fossils; differences are noted between Asian H. erectus compared to $H$. neanderthalensis and $H$. sapiens, but this feature do not separate the samples from Sangiran-Trinil and Ngandong-Sambungmacan, (6) the breadth of the precentral gyrus is superior to the breadth of the post-central gyrus on Ngandong samples as well as on European hominins, contrarily to African specimens and Sangiran-Trinil group; this feature distinguishes the two Javanese fossil series but is not to be considered as an autapomorphy, (7) the position of the occipital lobes, located in the prolongation of the parietal lobes on Sangiran-Trinil hominins, is nearly the same on more recent Javanese sample, this primitive character is not observed on $H$. neanderthalensis and H. sapiens. From the cladists' point of view, Solo series and Sangiran-Trinil are split in two different categories, as is the case in the two former kinds of approaches.

\section{Intra " $H$. erectus" diversity or several species ?}

How should the "young" Indonesian hominin fossils of the Solo River be interpreted? "Classic" and "evolved" H. erectus are demonstrated to belong to two distinct categories or even clades. Does H. erectus represent multiple hominid species, as formulated by Kramer (1993) and suggested by Schwartz and Tattersall (2000)? The Trinil-Sangiran series, including the type specimen Trinil, can be considered as the real and legitimate $H$. erectus. In contrast, the Solo populations, which form a unique, homogeneous series were initially referred to either H. soloensis (Oppenoorth, 1932; Durband, 2007), or H. sapiens soloensis (Dubois, 1940; Campbell, 1963; Jelinek, 1981; Tobias, 1985; Stringer, 1987; Bonde, 1989; Braüer and Mbua, 1992; see also Widianto and Zeitoun, 2003). It is difficult - if not impossible - to choose appropriate criteria to define fossil species, except for the criterion of monophyly from the cladistics point of view. Following traditional anthropological procedure, the way to split the clusters of fossils is based on a legal definition of the taxa, as in the Classical Evolutionary Systematic. This procedure did not and does not bring light to the debate because it mainly depends on opinions, not on demonstrations. The validity, or at any rate, the consistency of such a result (two anatomical categories) by comparison with chronological and environmental data can be tested. The question of biogeographical variance among humans is thus the only relevant level of discussion. But while the data show a chronological gap with drastic environmental events, the morphological differences are the strongest. However, the boundary between species or subspecies is randomly defined. It is nevertheless noteworthy that recent work (Clark Howell, 1999; Durband, 2002, 2006, 2007; Détroit, 2002; Tattersall and Schwartz, 2009) also considers Solo men as possibly belonging to another taxon. H. soloensis could be the most appropriate name. A parallel can be evoked from Europe with the chronological and evolutional succession of $H$. heidelbergensis and $H$. neanderthalensis. Finally, the use of the biological concept of species is absolutely not adequate for paleoanthropology.

\section{Environmental and chronological limits for two human categories}

It is and it will always be conjectural to explain what triggered human evolution. Naturalist, socioeconomical or cognitive approaches can be used for that purpose but will ever remain hypothetical. Nevertheless, it is a fact that if evolutionary processes occur under constraints or after environmental events, shifts or pressures of the latter can be interpreted as being the cause of the former. They are just interpretations or conjectures but data has to be collected to permit questions to be answered, and observations have to be made to strengthen or refute conjectures. When the phylogenetic pattern (Fig. 5) is placed in the chronological frame, many speciations appear to be concentrated in a relatively short time (Fig. 6). Four human categories are living together due to a human radiation. This result is consistent with Stringer's proposal (1986, p. 290) who suggested that at the beginning of the Homo lineage a radiation must have existed with at least three Plio-Pleistocene species of "early" Homo. In accordance with two environmental shifts identified in East Africa, a migration out of Africa is possible at that time for some populations as soon as 1.8 Ma when the humidity returned in East Africa (Zeitoun, 2000b). This scenario is consistent with the occurrence of Dmanisi series in Georgia (Gabunia and Vekua, 1995; Lumley et al., 
2002), and H. erectus in East Africa and Indonesia (Jacob and Curtis, 1971; Swisher et al., 1994). Who are the European hominins which made stone tools over 1.2 Ma (Martı'nez-Navarro et al., 1997; Toro-Moyano et al., 2003; Arzarello et al., 2006, 2009; Pare' s et al., 2006; Carbonell et al., 2008)? Are they the direct ancestors of Neandertals (Bermudez de Castro et al., 1997) or have they been replaced by more recent populations around $1.0 \mathrm{Ma}$ (see Carbonell et al., 2005)? What about Asia and the case of "archaic" H. sapiens or "advanced" $H$. erectus concerning the former and older category H. erectus sensu stricto? Are there two similar evolutionary phenomena in Far-eastern Asia and Far-western Europe? As mentioned above from three different methodological analyses, apart from the case of Flores, at least two categories existed in Indonesia. Focusing on Asia and considering the case of Solo men is far removed from the classical studies that considered these fossils as a geographic morph of $\mathrm{H}$. erectus but fits well with the suggestion made by the works of Schwartz and Tattersall (2000), Kidder and Durband (2004), and Durband (2002, 2006, 2007, 2009). Is it possible to shed some light on the Asian question from independent domains such as chronology and the environment as it has been proposed above for East Africa? In terms of pure cladistics, to use chronological data is not so rigorous for taxonomy since the work of Shaeffer et al. (1972), but Weidenreich (1943, p. 139) previously stated that, "it is certainly not allowed to consider one form as primitive uniquely because it is geologically older than another or to consider it as being derived simply because it is more recent."

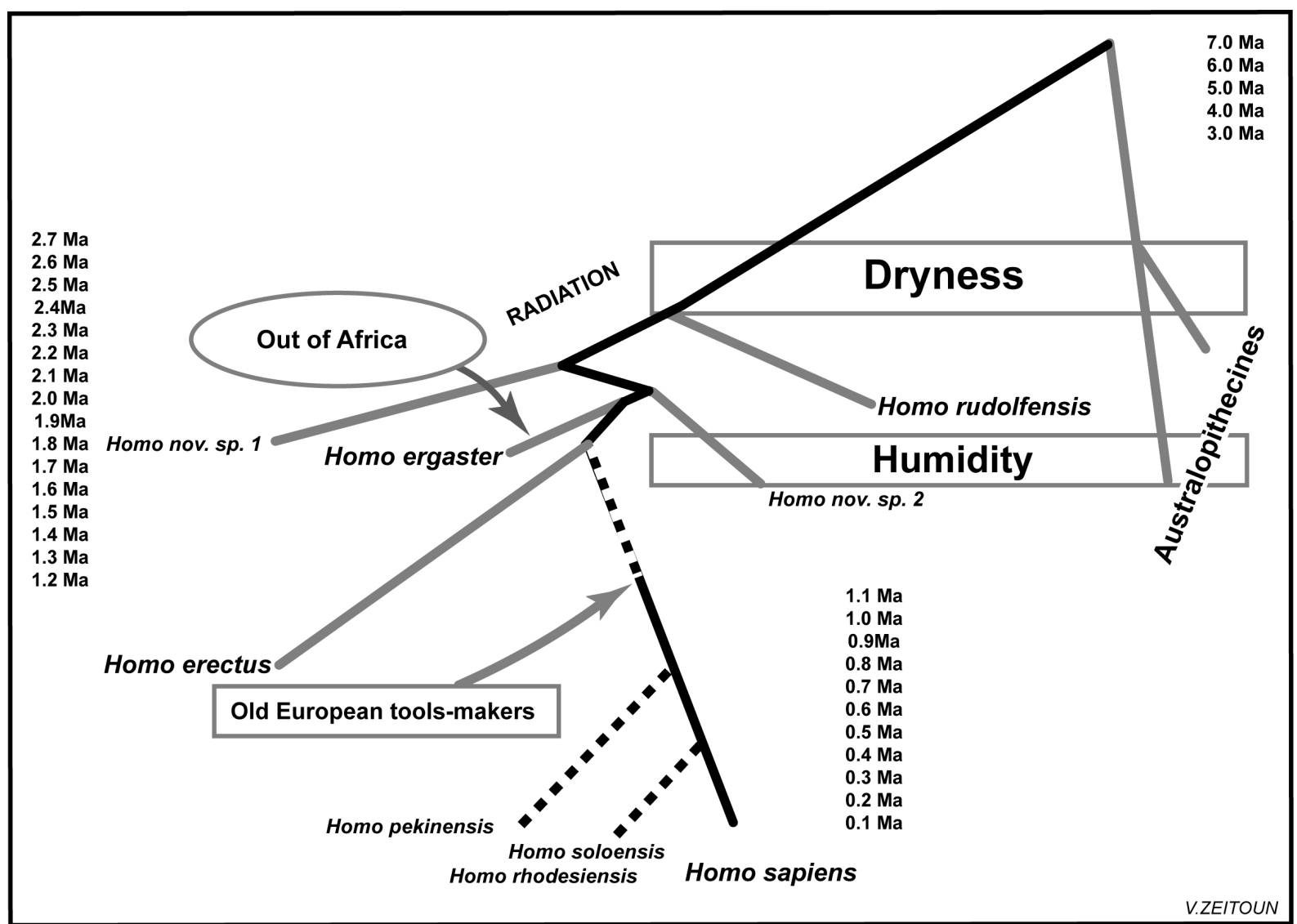

Fig. 6.

Chronological framework and environmental data. Between 2.5 and $1.8 \mathrm{Ma}$ some radiations occurred in East Africa among several taxa including human after a drought and before a relative return of humidity that may trigger the "major" first human Out of Africa event.

\section{Chronological gap}

From a global view, Java is a small territory where two Pleistocene human populations can be anatomically and morphometricaly recognized and cladistically split. The "classic" H. erectus date back to $1.8 \mathrm{Ma}$ (Jacob and Curtis, 1971; Swisher et al., 1994) or at least to more than $1.5 \mathrm{Ma}$ (Larick et al., 2001), even if formerly the most commonly accepted age for these fossils was about 1.0 Ma (De Vos et al., 1982; Leinders et al., 1985; Se' mah, 1986; Ithara et al., 1994). The "evolved" H. erectus were usually said to be present at about 80,000 to 250,000 years (Jacob, 1984; Barstra et al., 1988; De Vos et al., 1993). Recently, new dates provided an age ranging from 27,000 to ca 60-70,000 years for the Ngandong series (Swisher et al., 1996; Yokoyama et al., 2008) and from 35,000 to 60,000 years for Sambungmacan 1 (Falguères et al., 2001; Yokoyama et al., 
2008). Consequently, within the frame of a longer chronology (from $1.8 \mathrm{Ma}$ to 30,000 years), there is a wider chronological gap between the "classic" and the "evolved" populations. The establishment of the chronology for the hominid fossils from Java is a long story, full of confusion and controversies due to complex geological settings and the absence or loss of information for key fossils (Langbroek and Roebroeks, 2000). Thus, problems still remain because of uncertainty about the stratigraphical position of the fossils (Laitman and Tattersall, 2001). The uncertainty is also due to different interpretations or readings of the same data (Barstra, 1994; Hyodo et al., 1993; Sémah et al., 1992, 2000). Another kind of objection could be raised because of the use of indirect radiometric dating, but Falguères et al. (2001) and Yokoyama et al. (2008) applied direct methods on the skull of Sambungmacan 1, which provided dating that is consistent with the former work of Swisher et al. (1996). For the older "classic" Javanese H. erectus, arguments from field observations and literature put forward by Huffman (2001) are convincing enough to support the data of Swisher et al. (1994). Thus, following the hypothesis of a more "elastic" chronological framework, the evidence of a phylogenetic splitting between two kinds of " $H$. erectus" prompts consideration of the significance of a biological continuity between both "classic" and "evolved" H. erectus.

\section{Environmental clash}

Catastrophic events occurred around the Brunhes/Matuyama geomagnetic reversal (Fontaine, 1976; Schneider et al., 1992; Bunopas et al., 1999). They are known as the Australasian tektite strewn field that is dated to about 770,000 years ago (or 803,000 years ago by Hou et al., 2000). Such an event must have triggered shifting among the Asian populations and their environment. Another environmental event that happened 71,000 years ago: the explosion of the Toba volcano in Sumatra (Chesner et al., 1991; Zielinski et al., 1996), spewed ash rains as far off as India (Acharyya and Basu, 1993). This explosion, recorded up to the northern polar ice sheet (Lang et al., 1999) is synchronous with the drop of $16 \mathrm{C}^{\circ}$ recorded in the ice core of Greenland. This volcanic event is considered to have had drastic global consequences on human ecology and evolutionary processes (Ambrose, 1998). If this scenario is true at a global level, it seems even more crucially important for South-East Asia. Consequently, both Plio-Pleistocene events (comet and giant volcano eruption) could have triggered an intermittent disappearance of hominins in Java or at least a strong selective pressure and an important bottleneck in population demography.

\section{Conclusion}

The central problem remains of bridging the gap between individual specimens and at a higher level in order to achieve an appreciation of the subspecies and its variation. In the paleontological records, it is another step in the survey, which is in fact an unanswered question and can only be "solved" by arbitrary nomenclatural decisions. Nevertheless, it brings an opportunity to reconsider a belief that prevailed many years ago, when human fossils were not as numerous as they are now: Solo men as tropical Neandertals (Koenigswald,1958). Of course, the Ngandong-Ngawi-Sambungmachan series is not considered to be Neandertalian in the literal sense. But in the same chronological period than Neandertals, Solo men are belonging to a peripheral, geographically restricted hominin category which evolved in a marginal environment (Barstra, 1994; Grimaud-Hervé, 2004). If Neandertals evolved from an isolated population in the rather cold westernmost Eurasia, the Solo men could have evolved in the intermittently isolated insular or peninsular tropical easternmost Eurasia. Environmental shifting is synchronous with human changes. In Asia, environmental data could give some clues or at least other perspectives on regional human evolution. Indeed, around $0.8 \mathrm{Ma}$ ago Australasian tektites provide evidence of a cataclysmic event that may have drastically disturbed the local inhabitants or led to their disappearance. This hypothesis is consistent with the work of Larick et al. (2001) claiming that the stratigraphically highest human remains recovered from the site of Sangiran are derived from layers situated above the tektite layer. If this were not the case, the survivors or at least, those who replaced them must have been subjected to other regional drastic events that had a global climatic impact around 71,000 years ago with the giant explosion of the Toba volcano. Both events strongly suggest the disappearance or at least a disturbance of "classic H. erectus" populations. Are their survivors H. soloensis or H. sapiens? At least they are no longer the

former original $H$. erectus. Further regional faunistic and floristic data would need to be collected to test the very close link between environmental shifts and human evolution in this part of the Old World. This is also a general and theoretical model for the first European tool-makers that are not yet anatomically categorized. 


\section{Acknowledgments}

We would like to thank Sastrohamidjojo Sartono, Teuku Jacob, John De Vos, Jens Franzen, Fachroel Aziz, Mr Himawan and Etik Indriati who facilitated our access to the material. We thank Christophe Falguères and an anonymous reviewer for constructive comments. Marie-Hélène Moncel has to be thanked for our Far-eastern intrusion in the brain-storming of the oldest human expansion in Eurasia.

\section{References}

Acharyya, S., Basu, P., 1993. Toba ash on the Indian subcontinent and its implications for correlation of Late Pleistocene alluvium. Quaternary Research 40,10-19.

Ambrose, S., 1998. Late Pleistocene human population bottlenecks, volcanic winter, and differentiation of modern humans. Journal of Human Evolution 34, 623-651.

Arzarello, M., Marcolini, F., Pavia, G., Pavia, M., Petronio, C., Petrucci, M., Rook, L., Sardella, R., 2006. Evidence of earliest human occurrence in Europe: The site of Pirro Nord (Southern Italy). Naturwissenschaften 94, 107-112.

Arzarello, M., Marcolini, F., Pavia, G., Pavia, M., Petronio, C., Petrucci, M., Rook, L., Sardella, R., 2009. L'industrie lithique du site Pléistocène inférieur de Pirro Nord (Apricena, Italie du sud): une occupation humaine entre 1,3 et 1,7 Ma. L'Anthropologie 113, 47-58.

Baab K.L., 2008. The taxonomic implications of cranial shape variation in Homo erectus.Journal of Human Evolution 54, 827-847.

Baba, H., Aziz, F., Kaifu, Y., Suwa, G., Kon, R.T., Jacob, T., 2003. Homo erectus calvarium from the Pleistocene of Java. Science 299, 1384-1388.

Balzeau A., 2005. Spécificités des caractères morphologiques internes du squelette céphalique chez Homo erectus. Ph.D. dissertation, Museum National d'Histoire Naturelle, Paris.

Balzeau, A., Jacob, T., Indriati, E., 2002. Structures crâniennes internes de l'Homo erectus Sambungmacan 1 (Java, Indonésie). Comptes Rendues Palevol 1, 305-310.

Barstra, G., Soegondho, S., Van der Wijk, A., 1988. Ngandong man: age and artefacts. Journal of Human Evolution 17, 325-337.

Barstra, G., 1994. Indonesia in the period of Homo sapiens neanderthalensis and contemporaries. In: De Laet, S. (Ed.), History of Humanity. UNESCO, Paris, pp.167-171.

Bermudez de Castro, J.-M., Arsuaga, J.-L., Carbonell, E., Rosas, A., Martinez, I., Mosquera, M., 1997. A hominid from the Lower Pleistocene of Atapuerca, Spain: possible ancestor to Neandertals and modern humans. Science 276, 1392-1395.

Bonde, N., 1989. Erectus and neanderthalensis as species or subspecies of Homo with a model of speciation in hominids. In: Jiacomo, E. (Ed.), Hominidae. Proceedings, 2nd International Congress of Human Paleontology. Jaca Book, Milan, pp. 205-208.

Bookstein, F.L., 1991. Morphometric Tools for Landmark Data: Geometry and Biology. Cambridge University Press, New York.

Bouée, S., Détroit, F., 2008. Diversité taxonomique des Hominidés fossiles en Asie: de nouvelles méthodes pour une vieille question. Bulletins et Mémoires de la Société d'Anthropologie de Paris 20, 13-31.

Braüer, G., Mbua, E., 1992. Homo erectus features used in cladistics and their variability in Asian and African hominids. Journal of Human Evolution 22, 79-108.

Broadfield, D., Holloway, R., Mowbray, K., Silvers, A., Yuan, M., Marquez, S., 2001. Endocast of Sambungmacan 3 (Sm3): a new Homo erectus from Indonesia. Anatomical Record 262, 369-379.

Brown, P., 1981. Artificial cranial deformation: a component in the variation in Pleistocene Australian Aboriginal crania. Archaeology in Oceania 16, 156-167.

Brown, P., 1989. Coobool creek: a morphological and metric analysis of the crania, mandibles and dentitions of a prehistoric Australian human population. Terra Australis 13. 205 p.

Brown, P., 1994. Cranial vault thickness in Asian Homo erectus and Homo sapiens. Courier forschunginstitut Senckenberg 171, 33-46.

Bunopas, S., Wasson, J., Vella, P., Fontaine, H., Hada, S., Suphajunya, T., Khositanont, S., 1999. Catastrophic loess, mass mortality and forest fires suggest that a Pleistocene cometary impact in Thar land caused the Australasian tektite field. Journal of the Geological Society of Thailand 1,1-17.

Campbell, B., 1963. Quantitative taxonomy and human evolution. In: Washburn, S.L. (Ed.), Classification and Human Evolution. Aldine, Chicago, pp. 50-74.

Carbonell, E., Bermudez de Castro, J., Arsuaga, J., Allue, E., Bastir, M., Benito, A., Caceres, I., Rodriguez, J., Rodriguez, X., Rosas, A., Rosell, J., Sala, R., Vallverdu, J., Verges, J., 2005. An early Pleistocene homini 
mandible from Atapuerca-TD6, Spain. Proceedings of the National Academy of Sciences 102 (16), 56745678.

Carbonell, E., Bermudez de Castro, J., Pare, J.M., Perez-Gonzalez, A., Cuenca- Bescos, G., Olle, A., Mosquera, M., Huguet, R., van der Made, J., Rosas, A., Sala, R., Vallverdu, J., Garcia, N., Granger, D.E., Martinon-Torres, M., Rodriguez, X.P., Stock, G.M., Verges, J.M., Allue, E., Burjachs, F., Caceres, I., Canals, A., Benito, A., Diez, C., Lozano, M., Mateos, A., Navazo, M., Rodriguez, J., Rosell, J., Arsuaga, J.L. 2008. The first hominin of Europe. Nature 452, 465-470.

Chesner, C., Rose,W., Deino, A., Drake, R.,Westgate, J., 1991. Eruptive history of earth's largest Quaternary caldera (Toba, Indonesia) clarified. Geology 19, 200-203.

Clark Howell, F., 1999. Paleo-demes, species clades, and extinctions in the Pleistocene hominin record. Journal of Anthropological Research 55, 191-243.

Claude, J., 2008. Morphometrics with R. Springer, Berlin, 315 pp.

De Vos, J., Sartono, S., Harditja-Sasmita, S., Sondaar, P.-Y., 1982. The fauna from Trinil, type locality of Homo erectus; a reinterpretation. Geologie en Mijnbouw 4, 207-211.

De Vos, J., Aziz, F., Sondaar, P.-Y., 1993. Les faunes quaternaires de Java. Les dossiers de l'archéologie 184, 56-61.

Delson, E., Harvati, K., Reddy, D., Marcus, L.F., Mowbray, K., Sawyer, G.J., Jacob, T., Marquez, S., 2001. The Sambungmacan 3 Homo erectus calvaria: a comparative morphometric and morphological analysis. The Anatomical Records 262, 380-397.

Détroit F., 2002. Origine et evolution des Homo sapiens en Asie du sud-Est: descriptions et analyses morphome' triques de nouveaux fossiles. Ph.D. dissertation, Museum National d'Histoire Naturelle, Paris. $444 \mathrm{pp}$.

Dobzhansky, Th., 1944. On species and races of living and fossil man. American Journal of Physical Anthropology 2, 251-256.

Dryden, I., Mardia, K.V., 1998. Statistical Shape Analysis. John Wiley and Sons.

Dryden, I., 2009. Package 'shapes' - statistical shape analysis. Help documentation, Available from: http://www.maths.nott.ac.uk/wild/shapes.

Dubois, E., 1940. The fossil human remains discovered in Java by G.H.R. von Koenigswald and attributed by him to Pithecanthropus erectus in reality remains of Homo sapiens soloensis. Nederlandse Akademie van Wetenschappen 43, 841-854.

Durband, A., 2002. The view from down under: A test of the multiregional hypothesis of modern human origins using the basicranial evidence from Australasia. Acts of the XVII ${ }^{\text {th }}$ Congress of the Indo Pacific Prehistory association,Taipei.

Durband, A., 2006. Craniometric variation within the Pleistocene of Java: The Ngawi 1 cranium. Human Evolution 21, 193-201.

Durband, A., 2007. The view from down under: a test of the multiregional hypothesis of modern human origins using the basicranial evidence from Australasia. Collections in Anthropology 3, 651-659.

Durband, A.C., 2009. Southeast Asian and Australian palaeoanthropology: a review of the last century. Journal of Anthropological Sciences 87, 7-31.

Falguères, C., 2001. Dating layers and fossils in Sangiran dome: methods and results. In: Simanjuntak, Truman, Prasetyo, Bagyo, Handini, Retno (Eds.), Sangiran: man, culture and environment in Pleistocene times/Proceedings of the International Colloquium on Sangiran, Solo, Indonesia, 21-24 September 1998. Yayasan Obor, Jakarta, Indonesia, pp. 309-319.

Falguères, C., Yokoyama, Y., Jacob, T., Sémah, F., 2001. Advancements in the dating of Solo Man. Actes du XIVème Congrès de l'Union Internationale des sciences préhistoriques et protohistoriques, Liège.

Fontaine, H., 1976. Les tektites du Vietnam mé ridional. Comptes Rendus de la Société de Géologie 2, $37-$ 40.

Gabunia, L.K., Vekua, A.K., 1995. A Plio-Pleistocene hominid from Dmanisi, East Georgia, Caucasus. Nature 373, 509-512.

Grimaud-Hervé, D., 1997. L'évolution de l'encéphale chez Homo erectus et Homo sapiens, exemple de l'Asie et de l'Europe. Cahiers de Paléoanthropologie.Editions CNRS, Paris.

Grimaud-Hervé, D., 2004. Endocranial vasculature. In: Holloway, R.H., Broadfield, D.C., Yuan, M.S. (Eds.), The Human Fossil Record. Brain Endocasts, The Paleoneurological Evidence, vol. 3. Wiley Press, New York, pp. 273-282.

Grimaud-Hervé, D., Sartono, S., Widianto, H., Djubiantono, T., 1998. The fossil hominid from Ngawi. Indo-Pacific Association Bulletin 17, 42. 
Harvati, K., 2003. The Neanderthal taxonomic position: models of intra- and interspecific craniofacial variation. Journal of Human Evolution 44 (1), 107-132.

Harvati, K., Frost, S.R., McNulty, K., 2004. Neanderthal taxonomy reconsidered: implications of 3D primate models of intra- and interspecific differences. Proceedings of the National Academy of Sciences 101 (5), 1147-1152.

Hawks, J., Oh, S., Hunley, K., Dobson, S., Cabana, G., Dayalu, P., Wolpoff, M.H., 2000. An Australasian test of the recent African origin theory using the WLH-50 calvarium. Journal of Human Evolution 39 (1), $1-22$.

Hennig, W., 1966. Phylogenetic systematics. University of Illinois Press, Urbana.

Hlusko, L., 2004. Integrating the genotype and phenotype in hominid paleontology. Proceedings of the National Academy of Sciences 101, 2653-2657.

Holloway, R.L., 1980. Indonesian "Solo" (Ngandong) endocranial reconstructions: some preliminary observations and comparisons with Neandertal and Homo erectus groups. American Journal of Physical Anthropology 53 (2), 285-295.

Hou, Y., Potts, R., Baoyin, Y., Zhengtang, G., Deino, A., Wei, W., Clark, J., Xi, G., Huang, W., 2000. MidPleistocene acheulean-like stone technology of the Bose Basin, South China. Science 287, 1622-1626.

Huffman, O., 2001. Geological context and age of the Perning/Modjokerto Homo erectus, East Java. Journal of Human Evolution 40, 353-362.

Hyodo, M., Watanabe, N., Sunata, W., Edi Suanto, E., Wahyono, H., 1993. Magnetostratigraphy of Hominid fossil bearing formations in Sangiran and Modjokerto, Java. Anthropological Science 101, 157-186.

Ithara, M., Watanabe, N., Kadar, D., Kumai, H., 1994. Quaternary stratigraphy of the Hominid fossil bearing formations in the Sangiran area, central Java. Courier Forschung Institut Senckenberg 171, 123-128.

Jacob, T., 1978. The puzzle of Solo Man. Modern Quaternary Research in South East Asia 4, 31-40.

Jacob, T., 1984. The fossil skull cap from Sambungmachan and its implication to human evolution. Berkala Bioanthropologi Indonesia 1, 19-27.

Jacob, T., Curtis, G., 1971. Preliminary potassium-argon dating of early man in Java. Contributions University of California, Archeological Dating Facility 12, 50.

Jelinek, J., 1981. Was Homo erectus already Homo sapiens? In: Ferembach, D. (Ed.), Les processus de l'hominisation. CNRS, Paris, pp. 85-89.

Kidder, J., Durband, A., 2004. A re-evaluation of the metric diversity within Homo erectus. Journal of Human Evolution 46, 297-313.

Koenigswald, vonG.H.R.,1958.Der Solo-MenschvonJava: eintropischerNeanderthaler. Hundert Jahre Neanderthaler. Bo"hlau-Verlag, Köln, pp. 21-261856-1956.

Kramer, A., 1993. Human taxonomic diversity in the Pleistocene: does Homo erectus represent multiple hominid species? American Journal of Physical Anthropology 91, 161-171.

Laitman, J., Tattersall, I., 2001. Homo erectus newyorkensis: An Indonesian fossil rediscovered in Manhattan sheds light on the middle phase of Human evolution. The Anatomical Record 262, 341-343.

Lang, C., Leuenberger, M., Schwande, J., Johnsen, S., 1999. 16 _C rapid temperature variation in Central Greenland 70, 000 years ago. Science 286, 934-936.

Langbroek, M., Roebroeks, W., 2000. Extraterrestrial evidence on the age of the hominids from Java. Journal of Human Evolution 38, 595-600.

Larick, R., Ciochon, R., Zaim, Y., Sudijono, Suminto, Rizal, Y., Aziz, F., Reagan, M., Heizler, M., 2001. Early Pleistocene $40 \mathrm{Ar} / 39 \mathrm{Ar}$ ages for Bapang formation hominins, central Java, Indonesia. Proceedings of the National Academy of Sciences 98, 4866-4871.

Leinders, J., Aziz, F., Sondaar, P.-Y., De Vos, J., 1985. The age of the hominid-bearing deposits of Java: state of the art. Geologie en Mijnbouw 64, 167-173.

Liptak, P., 1969. On the evolutionary systematics of Hominidae. Symposium Biologica Hungarica 8, 107111.

Lumley, H.de, Lordkipanidze, D., Féraud, G., Garcia, T., Perrenoud, C., Falguères, C., Gagnepain, J., Saos, T., Voinchet, P., 2002. Datation par la me thode ${ }^{40} \mathrm{AR} /{ }^{39} \mathrm{Ar}$ de la couche de cendres volcaniques (couche VI) de Dmanissi (Géorgie) qui a livré des restes d'hominide's fossiles de 1,81 Ma. Comptes Rendues Palevol 1,181-189.

Macintosh, N., Larnach, S., 1972. The persistence of Homo erectus traits in Australian aboriginal crania. Archaeology and Physical Anthropology in Oceania 7, 1-7.

Martinez-Navarro, B., Turq, A., Agust1', J., Oms, O., 1997. Fuente Nueva-3 (Orce, Granada, Spain) and the first human occupation of Europe. Journal of Human Evolution 33, 611-620. 
Mayr, E., 1957. Species concepts and definitions. In: Mayr, E. (Ed.), The Species Problem, 50. American Association of Advanced Science Publications, pp.1-22.

Moncel, M.-H., 2008. L'expansion humaine en Eurasie de 1.8 à 0.5 Ma: les données, les questions et les hypothèses. In: Bocquet-Appel, J.P. (Ed.), La Paléodémographie: 99.99\% de l'histoire démographique des hommes ou la démographie de la Préhistoire. Eds Errance, pp. 45-70.

Oppenoorth, W.F., 1932. Homo (Javanthropus) soloensis, enPleistocene mensch van Java. Wetenschapelijke Medische Dienst Mijnbouw Nederlandsch Indië 20, 49-74.

Oppenoorth, W.F., 1937. The place of Homo soloensis among fossil men. In: Maccurdy, G. (Ed.), Early Man. 349-360, Philadelphia.

Parés, J.M., Pérez-Gonzalez, A., Rosas, A., Benito, A., Bermu’ dez de Castro, J.M., Carbonell, E., Huguet, R., 2006. Matuyama-age lithic tools from the Sima del Elefante site, Atapuerca (northern Spain). Journal of Human Evolution 50, 163-169.

R Development Core Team., 2009. R: A Language and Environment for Statistical Computing, Reference Index Version 2.9.0. R Foundation for Statistical Computing, Vienna, Austria, ISBN 3-900051-07-0. http://www.R-project.org.

Rightmire, P., 1986. Species recognition and Homo erectus. Journal of Human Evolution 15, 823-826.

Rightmire, P., 1996. The human cranium from Bodo, Ethiopia: evidence for speciation in the Middle Pleistocene? Journal of Human Evolution 31, 21-39.

Salecki, H., 1997. Apport d'une intercomparaison de me' thodes nucle' aires $\left({ }^{230} \mathrm{Th} /{ }^{234} \mathrm{U}\right.$, ESR, et $\left.{ }^{40} \mathrm{Ar} /{ }^{39} \mathrm{Ar}\right)$ à la datation de couches fossilifères pléistocènes dans le dôme de Sangiran (Java central). PhD dissertation, Museum National d'Histoire Naturelle, Paris, 238 pp.

Santa Luca, A., 1980. The Ngandong fossil hominids. A Comparative Study of a Far Eastern Homo erectus Group. Yale University Publications in Anthropology, 78.175 pp.

Sartono, S., Grimaud, D., 1983. Les pariétaux des pithécanthropes Sangiran 12 et Sangiran 17. L'Anthropologie 87, 475-482.

Shaeffer, B., Hecht, M., Eldredge, N., 1972. Phylogeny and paleontology. Evolutionary Biology 6, 31-46.

Schneider, D., Kent, D., Mello, G., 1992. A detailed chronology of the Australasian impact event, the Brunhes-Matyama geomagnetic reversal, and global climate change. Earth and Planetary Sciences Letters 111, 395-405.

Schwartz, J.H., Tattersall, I., 2000. What constitutes Homo erectus? Acta Anthropologica Sinica 19 (Suppl.), 21-25.

Sémah, A.M., Détroit, F., 2006. Sur les premiers peuplements du Pacifique Sud. Comptes Rendus Palevol 5, 381-393.

Sémah, F., 1986. Le peuplement ancien de Java. Ebauche d'un cadre chronologique. L'Anthropologie 90, 359-400.

Sémah, F., Féraud, G., Salecki, H., Falguères, C., Djubiantono, T., 2000. Did early man reach Java during the late Pliocene? Journal of Archaeological Science 27, 763-769.

Sémah, F., Sémah, A.-M., Djubiantono, T., Simanjuntak, H.-T., 1992. Did they also make tools? Journal of Human Evolution 23, 439-446.

Shen, G., Gao, X., Gao, B., Granger, D., 2009. Age of Zhoukoudian Homo erectus determined with ${ }^{26 \mathrm{Al} /}{ }^{10} \mathrm{Be}$ burial dating. Nature 359, 198-200.

Slice, D. (Ed.), 2005. Modern Morphometrics in Physical Anthropology. Kluwer Academy/Plenum Publishing, New York.

Smith, T.M., Tafforeau, P., Reid, D.J., Gru“ n, R., Eggins, S., Boutakiout, M., Hublin, J.-J., 2007. Earliest evidence of modern human life history in North African early Homo sapiens. Proceedings of the National Academy of Sciences 104 (15),6128-6133.

Stringer, C.B., 1986. The credibility of Homo habilis. In: Wood, B., Martin, L., Andrews, P. (Eds.), Major Topics in Primate and Human Evolution. Cambridge University Press, Cambridge, pp. 266-294.

Stringer, C.B., 1987. A numerical cladistic analysis for the genus Homo. Journal of Human Evolution 16, 135-146.

Stringer, C.B., 1998. A metrical study of the WLH-50 calvaria. Journal of Human Evolution 34, 327-332.

Stringer, C.B., 2002. Modern human origins: progress and prospects. Philosophical Transactions of the Royal Society (London) 357, 563-579.

Swisher, C., Curtis, G., Jacob, T., Getty, A., Suprijo, A., Widiasmoro., 1994. Age of the earliest known hominids in Java, Indonesia. Science 263, 1118-1121.

Swisher, C., Rink, J., Anton, S., Schwarcz, H., Curtis, G., Suprijo, A., Widiasmoro., 1996. Latest Homo erectus 
of Java: potential contemporaneity with Homo sapiens in Southeast Asia. Science 274, 1870-1874.

Tattersall, I., Schwartz, J., 2009. Evolution of the genus Homo. Annual Review of Earth Planetary Sciences 37, 67-92.

Terhune, C.E., Kimbel, W.H., Lockwood, C.A., 2007. Variation and diversity in Homo erectus: a 3D geometric morphometric analysis of the temporal bone. Journal of Human Evolution 53, 41-60.

Tobias, P., 1985. Single characters and total morphological pattern redefined the sorting effected by a selection of morphological features of the early hominids. In: Delson, E. (Ed.), Ancestors: The Hard Evidence. A.R. Liss, pp.94-101.

Toro-Moyano, I., Lumley, H., de, Barsky, D., Celiberti, V., Cauche, D., Moncel, M.H., Fajardo, B., Toro, M., 2003. Las industria l1'ticas de Barranco Leon y Fuenta Nueva 3 de Orce. Estudio Técnico y tipolo gico. Analisis traceologico. Resultados preliminares. In: Toro, I., Agusti, J., Martinez-Navarro, B. (Eds.), El Pleistoceno inferior de Barranco Leon y Fuenta Nueva 3, Orce (Granada). Memoria CientificaCampanas 1999-2002. Arqueologia Monografias, Consejeria de Cultura, Junta de Andalucia, pp. 183-206.

Weidenreich, F., 1943. The skull of Sinanthropus pekinensis: a comparative study. Palaeontologia sinica (New series D) 10,1-484.

Weidenreich, F., 1951. Morphology of Solo man. Anthropological Papers of the American Museum of Natural History 43, 205-322.

Widianto, H., 1993. Unité et diversité des hominidés fossiles de Java. Ph.D. dissertation, Museum National d'Histoire Naturelle, Paris.

Widianto, H., Grimaud-Hervé, D., 2001. The evolutionary position of the Ngawi: a morphological and biometrical analysis. I.P.P.A. (Melaka Papers) 21 (5), 162-169.

Widianto, H., Zeitoun, V., 2003. Morphological description, biometry and phylogenetic position of the skull of Ngawi 1 (East Java, Indonesia). International Journal of Osteoarchaeology 13, 339-351.

Yokoyama, Y., Falguères, C., Sémah, F., Jacob, T., Grün, R., 2008. Gamma-ray spectrometric dating of late Homo erectus skulls from Ngandong and Sambungmacan, Central Java, Indonesia. Journal of Human Evolution 55 (2), 274-277.

Zeitoun, V., 2000a. Révision de l'espèce Homo erectus (Dubois, 1893). Utilisation des données morphométriques en cladistique, reconsidération du cas Homo erectus. Bulletins et Mémoire de la Société d'Anthropologie de Paris 12,1-201.

Zeitoun, V., 2000b. Adéquation entre changements environnementaux et spéciations humaines au PlioPléistocène. Comptes Rendus de l'Académie des sciences 330, 161-166.

Zeitoun, V., 2004. Réconciliation des modèles « évolution multirégionale » et « sortie d'Afrique ». British Archaeological Research International Series 1271, 49-58.

Zeitoun, V., 2009. The Human canopy. British Archaeological Research. J and E Hedges.

Zielinski, G., Mayewski, P., Meeker, L., Whitelow, S., Twickler, M., 1996. Potential impact of the Toba megaeruption 71,000 years ago. Geophysical Research Letters 23, 837-840. 